\title{
Relationship between Covering Tension and Composition of
}

\section{Covered Yarn}

\author{
MORI Daisuke*, SHINTAKU Sukenori** and KINARI Toshiyasu ** \\ *Industrial Research Institute of Ishikawa Prefecture, Kuratsuki Kanazawa, 920-8203, Japan \\ **Department of Mechanical Engineering, Kanazawa University, Kodatsuno, Kanazawa 920-8667, Japan
}

Received 26 May 2003; accepted for publication 30 January 2004

\begin{abstract}
It is often to make a composite yarn for design and development of new textile products at textile industry in Japan. Covering process is one of methods in which two or more yarns are combined. And then, a composition of covering and core yarns in a covered yarn is an important factor for affecting the quality and characteristic of fabric.

Covering tension is theoretically estimated for clarifying a relationship between the composition of covering and core yarns and manufacturing condition in covering process. The covering tension increases with increasing the angular velocity of spindle and the balloon height. The composition of covering and core yarns decreases with increasing the ballooning tension.

In order to prevent the covering tension from decreasing with the change of bobbin radius for the covering yarn, a method of controlling the angular velocity of spindle has an effect for keeping a constant composition of covering and core yarns in a covered yarn.

Key Words: Balloon, Tension, Twist, Angular velocity of spindle, Covered yarn
\end{abstract}

\section{カバリング系の巻付け張力とカバード糸の構成比の関係}

\section{森大介* 新宅救徳** 喜成年泰**}

\section{1. 緒 㝘}

織維産業では織維製品の高付加価値化を図るため, 複数の 異なった糸による襀合化系加工が盛んに行われている. 複合 化系加工の一つとして, 芯系に別の系を螺旋状に巻付ける力 バリング加工がある. カバリング加工では, 従来から芯系に ポリウレタン系, カバリング系に合成緉維を用いたストレッ チ系等が多く生産されており，また，最近はカバリング糸に 機能性フィルムのスリット系等を用いたカバード系の製造 も行われている.

これらのカバード糸を用いた織物の風合いや品質を左右 する要因として, カバード系を構成する芯系とカバリング禾 の被覆状態がある.この被覆状態を評価する手法としては, カバード系の然数や然角度を調べる方法もあるが, 本研究で は，カパード禾を芯系とカバリング系に分解した後，これら の質量測定から，長さに换算することにより芯系に対するカ バリング系の長さの比（以下，カバード糸の構成比）を求め た.このカバード系の構成比に影歓を与える因子には, カバ
リング糸の巻付け張力と芯系張力がある. 著者の一人は, バ ルーニング中の糸が切断した場合に糸の切れ端は糸層にす べて巻付かず, 一定の半径を保って回転することから，この 半径をもって理論的にカバリング系の巻付け張力を求めた [1-2,4]. そこで, 本研究はカバード系の構成比とカバリン グ系の巻付け張力の関係を明らかにするため，実機で芯糸張 力を無視するに十分な剛性を有する系を芯系に用いてカバ 一ド系を作製し，これらのカバード糸の構成比と理論的に求 めたカバリング系の巻付け張力の関係について調へた。，一方， カバリングエ程でカバリング系の系居半径の堿少にともな ってカバリング系の巻付け張力が小さくなるためにカバー ド系の楼成比が増加するという問題がある.そこで，この問 題を解決するため, 巻付け㖘力の解析結果から系首半径が変 化した場合にカバリング糸の巻付け張力が一定となるスピ ンドル角速度を求め, 系層半径の変化に応じてスピンドル角 速度を変えてカバリングする手法について検討した.この手 法はスピンドル角速度が一定の場合と比較して,カバード釆 の構成比を安定させる効果があることを確認したので以下

* 連絡先 : 石川県工業試験場 920-8203 金沢市䩳月 2 丁目 1 番地, E-mail: daisuke@irii.go.jp, Fax: 076-267-8090

** 金沢大学工学部 920-8667 金沢市小立野 2-40-20 
に報告する。

\section{2. 巻付け張力の解析}

\section{1 バルーン解析}

カバリング糸の巻付け張力は, カバリング糸のバルーンの 解析から求めることができる．四1に示すように， $x$ 軸およ び $y$ 軸をボビンに対して直角平面上に， $z$ 軸はボビン軸上に とる. $x=y=z=0$ の点をバルーンの頂点とし, バルーン頂点で のカバリング系の張力をカバリング系の巻付け張力とする. このバルーン解析で空気抗力と遠心力を考虑した式は, (1) 〜 (3) となる[2-4].

$\frac{d P}{d\left(R^{2}\right)}=\left\langle P+\mu\left\{R^{2}-P^{2}\left(1-Q^{2}\right)\right\}^{1 / 2}\left(R^{2}-P^{2}\right)^{1 / 2}\right) /\left(\left(1-Q^{2}\right)\left(1-R^{2}\right)\right\}$

$\frac{d Q}{d\left(R^{2}\right)}=\left\langle Q-\mu\left\{R^{2}-P^{2}\left(1-Q^{2}\right)\right\}^{1 / 2} P Q\left(R^{2}-P^{2}\right)^{-1 / 2}\right\rangle /\left(1-R^{2}\right)$

$\frac{d(z / \ell)}{d\left(R^{2}\right)}=\frac{Q}{2\left(1-Q^{2}\right)^{1 / 2}\left(R^{2}-P^{2}\right)^{1 / 2}}$

ただし，

$H:$ バルーン高さ[m]

$T:$ 張力 $[\mathrm{N}]$

$m:$ 糸の線密度 $[\mathrm{kg} / \mathrm{m}]$

$C_{d}:$ 糸の垂直な方向の空気抗力係数

$D:$ 糸の直径 [m]

$\rho:$ 空気の密度 $\left[\mathrm{kg} / \mathrm{m}^{3}\right]$

$K: C_{d} D \rho / 2\left[\mathrm{~kg} / \mathrm{m}^{2}\right]$

$P$ : バルーンを $x, y$ 平面に投影した曲線の接線に回転中 心より下した垂線の長さをとで除した無次元長さ

$Q: \mathrm{d}(z / \ell) / \mathrm{d} s$ ( $s$ は線素)

$\ell:$ 仮想的に張力 0 となる半径 $[\mathrm{m}]$

$\mu: K \ell / m$

$R: r l \ell\left(た た ゙ し, x^{2}+y^{2}=r^{2}\right)$

$b:$ 糸層半径 $[\mathrm{m}]$

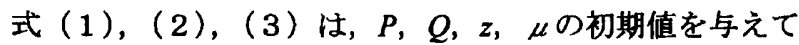
やれば, $R^{2}$ を変数として, 数值解析により解くことができる. $\mu$ は 1 以上の值を用いて, $R=0$ において $P=0, z=0$ とし， $Q$ の初期値を 1 以下の適当な数値を与えて計算する. $R=P$ とな るまで $R$ の増加方向に計算し，その後， $P=-P$ として $R$ の诚 少方向に計算する．最初に $R=P$ になる場合における $R(r / \ell)$ のrは最大径であり，その後， $R=P$ となる場合の $R(r / \ell)$ の $r$ は，系層半径の $b$ と一致し， $R$ は $b / \ell$ となりこの点に糸層が 存在すると考える. この点での $Q$ の值は, 糸が上方に向かっ て引き出される角度の正弦である.最初に $P=R$ となる点の $R$ を $R_{l}, R$ を減少方向にして再び $P=R$ となる点の $R$ を $R_{2}$ とす

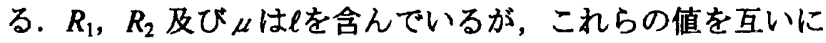

除することにより，バルーンに関する無次元長さを得る. $(z / \ell) / R_{2}$ はバルーン高さ $H$ と糸居半径 $b$ の比 $H / b$ である.こ れが所定の值にならなければ， $Q$ の初期值を変えて再び計算 する. $\mu R_{2}=K b / m$ であるから, $H / b$ をパラメータとして, $\ell / b$ と $K b / m$ の関保が求められ，これを図 2 に示した.

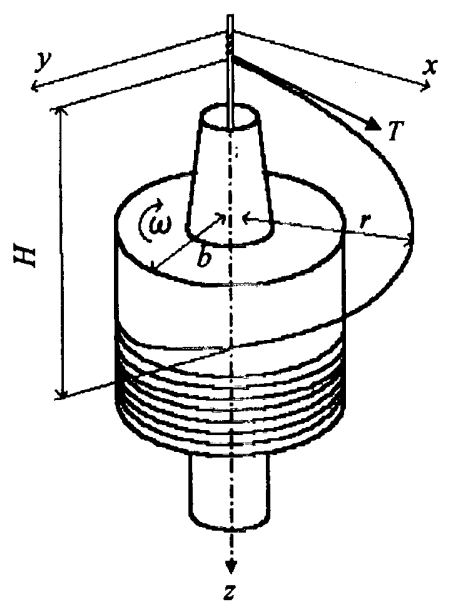

Fig.1 Covering apparatus

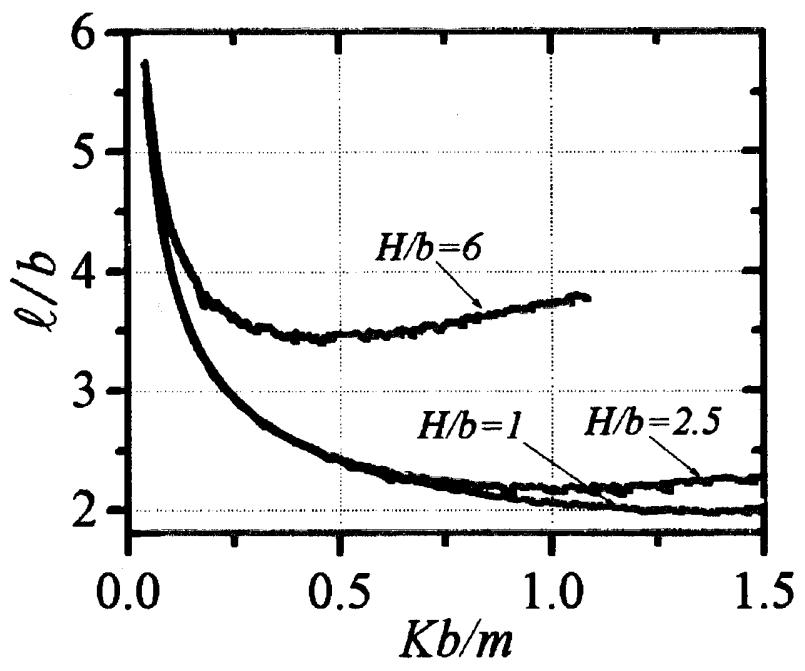

Fig. 2 Relation between $\ell / b$ and $K b / m$

\section{2 巻付け張力の求め方}

バルーンの解析により, 後述するラッシングエンド半径 $L$, 系層半径 $b$, 系の線密度 $m$, 及び $K$ の関俰から, 糸屏半径と ラッシングエンド半径を測定すれば, 図 4 より， $K$ と系層半 径の積を糸の線密度で除した無次元量が求まる.この值から， 図 2 よりバルーン中のカバリング系が張力0となる半径を系 居半径で除した無次元長さが求まり，これと类の線密度，ス ピンドル角速度及び糸局半径から式（4）より，巻付け張力 を求めることができる[2,4].

$$
T=m \omega^{2} b^{2}(\ell / b)^{2} / 2
$$


ただし，

$\omega:$ スピンドル角速度 $[\mathrm{rad} / \mathrm{s}]$

\section{2. $3 \mathrm{~K}$ の算定方法}

$K$ を算定するには, $C_{d}$ と $D$ を決定しなければならないが, バルーン中のカバリング系は系層から芯系に巻付くまでに レイノズル数が変化し空気抗力係数に幅がある. また, $D$ に ついては，投影機による直径ではなく，毛羽や撚の影響を考 慮した空気抗力に対する直径を用いなければならない. そこ で, ラッシングエンド半径を測定することで $K$ を算定する手 法を用いた[2].

精紡, 合系, あるいはカバリング等の工程において, 高速 回転する糸が切れると, 図 3 のようにボビン側の系はすべて 巻付かず, ある一定の半径を保ったまま回転する.この回転 の中心から系の先端までの半径 $L$ をラッシングエンド半径 といい, 先端から系層までの形状をラッシングェンド曲線と いう.このラッシングェンド半径およびラッシングェンド曲 線は系の線密度 $m$, 系層半径 $b, K$ によって決まり,この関 係を図 4 に示す [1].

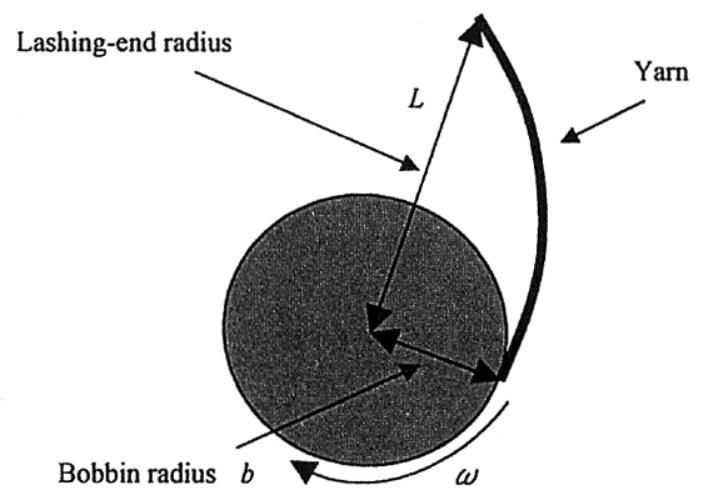

Fig.3 Lashing-end curve

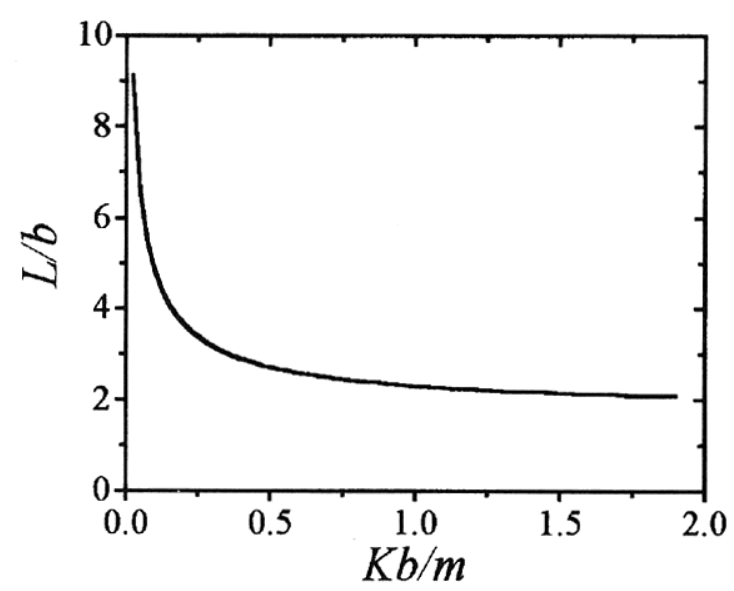

Fig.4 Relation between $L / b$ and $K b / m$

\section{4 ラッシングエンド半径の測定と巻付け張カ の計算}

$K$ の算定は $L$ を測定して決定する方法をとる. 実験に使用 した系を表 1 に示す. 実験は片岡機械工業侏製カバリングマ シン PF II 型を用いて, $b=16 \mathrm{~mm}$ のボビンに系を数回巻付けて, スピンドル回転数 $838 \mathrm{rad} / \mathrm{s}$ で実験を行った. ラッシングエン ド曲線の観察は, ストロボスコープを用いて直定規にて読み 取った．実験結果及び図 4 から読み取った $K b / m$ と $L / b$ の関 係を表 2 に示す。この結果より，Kが求まり，図 2 の結果か 5, 各 $H / b$ の $\ell / b$ が決定し, 式 (4) よりカバリング系の巻 付け張力 $T$ を求めることができる. 表 2 より， $b=32 \mathrm{~mm}$ にお ける $K b / m$ を求め, 図 4 及び式 (4) より巻付け張力を求め たので，その結果を図 5 に示す. スピンドル角速度の増加に ともない, 巻付け張力が増加することがわかる. また, 系層 半径に対するバルーン高さの比が大きくなるとカバリング 系の巻付け張力も増加する.さらに, $167 \mathrm{dtex} / 32 \mathrm{f}$ と 184dtex/48f を比較すると, 仮撚系 184dtex/48f の巻付け張力 は, $H / b$ が小さい（a ）では小さく, H/b が大きい（b ）で は大きくなっているが, その両者の巻付け張力はほぼ同じ值 となっている.これは, 両者の線密度や系の表面形状が異な っていることにより, 巻付け張力は $K b / m$ によって決定する $\ell / b$ の值の影響を受けるため, 両者の巻付け張力はほぼ同じ 值になったと考えられる.

Table 1 Details of yarn sample

\begin{tabular}{c|c|c|c|c}
\hline No. & Yarn type & No. of Filaments & Count(dtex) & Remark \\
\hline \multirow{3}{*}{ I } & \multirow{3}{*}{ Polyester } & 36 & 84 & \\
\cline { 1 - 4 } II & 32 & 167 & \\
\cline { 3 - 5 } III & & 48 & 184 & Textured Yarn \\
\cline { 3 - 5 } & & &
\end{tabular}

Table $2 L, b, m$ and $K$ for yarn sample

\begin{tabular}{c|c|c|c}
\hline No. & $L$ & $L / b$ & $K b / m$ \\
\hline \hline I & 0.0630 & 3.94 & 0.167 \\
\hline II & 0.0697 & 4.36 & 0.130 \\
\hline III & 0.0640 & 4.04 & 0.166 \\
\hline
\end{tabular}

\section{3. 巻付け張カとカバード糸の構成比 の関係}

\section{1 実験}

\subsection{1 実機による実験}

前述したカバリング系の巻付け張力はスピンドル角速度 やバルーン高さなどから求まるので, 実機により実験を行い, カバリング系の巻付け張力がカバード系に及ぼす影響につ いて調べた. 実験には, ラッシングェンド半径の測定と同様 に片岡機械工業㑣製カバリングマシン PF II 型を用いた。ま 


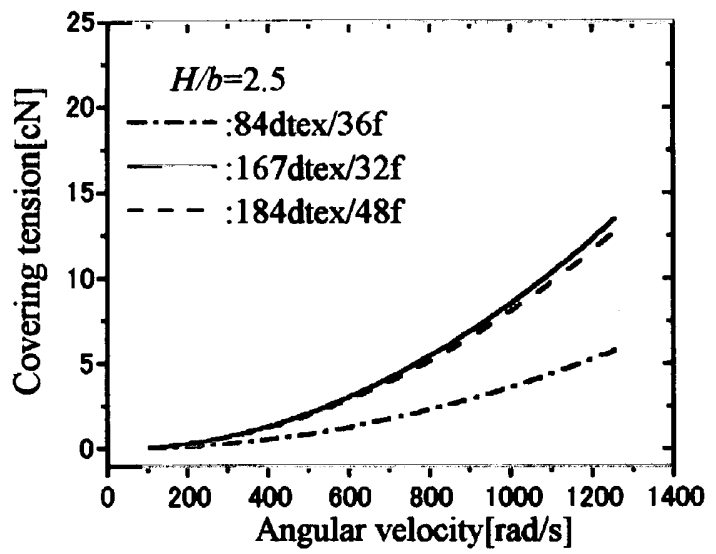

(a) Effect of yarn sample

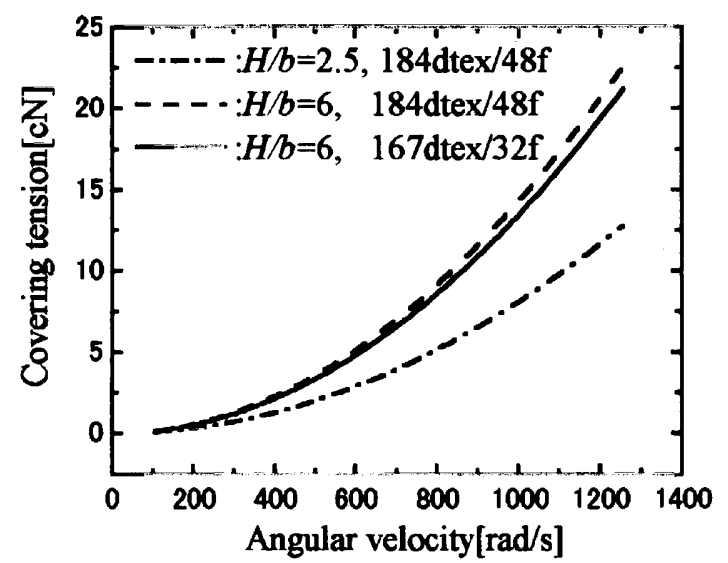

(b) Effect of $H / b$

Fig.5 Calculated covering tension and angular velocity of spindle

た, カバード糸の構成比にはカバリング系の巻付け㖘力だけ でなく，芯系掁力も影警を及ぼすと考えられるが，本研究で は巻付け張力だけを考虑するため, 芯系張力の影濢を無視す るに十分な㣚性を有するナイロン 1022dtex/f のモノフィラメ ント系を芯系として用いた。 また，カバリング系には，表 1 の 3 種類の系を使用した。さらに， $b=32 \mathrm{~mm}$ で一定としバル ーン高さをガイドにて調節し，スピンドル回転数を変えて実 験を行った．実験条件を表 3 に示す.

Table 3 Experimental conditions of covering process

$\left.\begin{array}{c|c}\hline \text { Covering machine } & \text { KATAOKA PF II } \\ \hline \text { Core yarn } & \text { Nylon 1022dtex/f } \\ \hline \text { Spindle velocity } & 419 \sim 1257 \mathrm{rad} / \mathrm{s} \\ \hline \text { Ratio between radius of yarn } \\ \text { layer and balloon height: } H / b\end{array}\right)$

\subsection{2 カパード糸の權成比}

カバード糸の構成比を求める手法として，カバード系を $10 \mathrm{~cm}$ の長さに切断し, 図6のように芯系とカバリング禾に 分解した後, これらの質量をマイクロ天秤 (メトラー製 MT5)
によって 5 回測定して，その平均値を系長に换算しカバード 糸の構成比 $\left(L_{2} / L_{1}\right)$ を求めた.

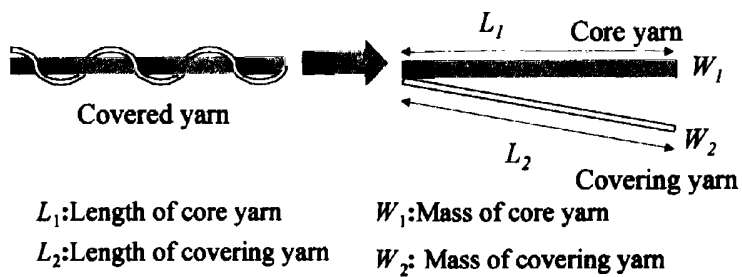

Fig. 6 Measurement for composition of covering and core yarns

\subsection{3 巻付け張力の制御}

前述のカバリング系の巻付け張力の解析より, 糸層半径が 変化してもカバリング糸の巻付け張力が一定となるスピン ドル角速度を求め, 系層半径の変化に応じてスピンドル角速 度を変えてカバリングを行い, スピンドル角速度が一定の場 合と比較を行った. 前述の芯系とカバリング系を用い, 初期 時のスピンドル角速度を $838 \mathrm{rad} / \mathrm{s}$ として実検を行った．初期 時の巻付け張力は，巻付け張力の解析より求めた $\ell b$ と式 （4）より $2.2 \mathrm{cN}$ と求まる.また, 系層半径を変化させた場 合において, 巻付け張力を一定とするスピンドル角速度も同 じ方法で求めた.この系層半径, スピンドル角速度及び巻付 け張力の関係の一例を表 4 に示寸. Case I は，スピンドル角 速度が 838 $\mathrm{rad} / \mathrm{s}$ で一定のため, 系層半径の减少にともなって 巻付け張力も小さくなっているが, Case II では, 巻付け張力 の解析を基に系既半径の变化に応じてスピンドル角速度を 変化させることにより, 巻付け張力が一定となる.

Table 4 Relation between $b, T$ and $\omega$

\begin{tabular}{|c|c|c|c|c|}
\hline \multirow{2}{*}{$b(\mathrm{~mm})$} & \multicolumn{2}{|c|}{ Case I } & \multicolumn{2}{|c|}{ Case II } \\
\hline & $\omega(\mathrm{rad} / \mathrm{s})$ & $T(\mathrm{cN})$ & $\omega(\mathrm{rad} / \mathrm{s})$ & $T(\mathrm{cN})$ \\
\hline 32 & & 2.2 & 838 & \\
\hline 30 & 020 & 2.1 & 858 & \\
\hline 25 & 000 & 1.7 & 940 & 2.2 \\
\hline 17 & & 1.2 & 1103 & \\
\hline
\end{tabular}

\section{2 結果と考察}

図 7 にスピンドル角速度 $838 \mathrm{rad} / \mathrm{s}$ における然数とカバード 糸の構成比の関係を示す，然数の增加にともなって $L_{2} / L_{1}$ は 増加しており, その勾配は然数が多くなるほど徐々に増加し ている.これは, 芯系にカバリング系が螺旋状に巻付くため, 热数が多くなるに従って, カバード系の構成比の增加率が大 きくなるためと考えられる.また, スピンドルの角速度とカ バード禾の構成比の関係を図 8 に示した. 然数が同じでもス ピンドル角速度の増加にともないカバード系の標成比は減 少し，それぞれの撚数に态じて一定の值に近づいている，そ の堿少率は然数が多いほど大きくなっている．これは，スピ ンドル角速度の増加にともなってカバリング系の巻付け張 カが大きくなりカバリング系が引っ張られた状態で芯系に 


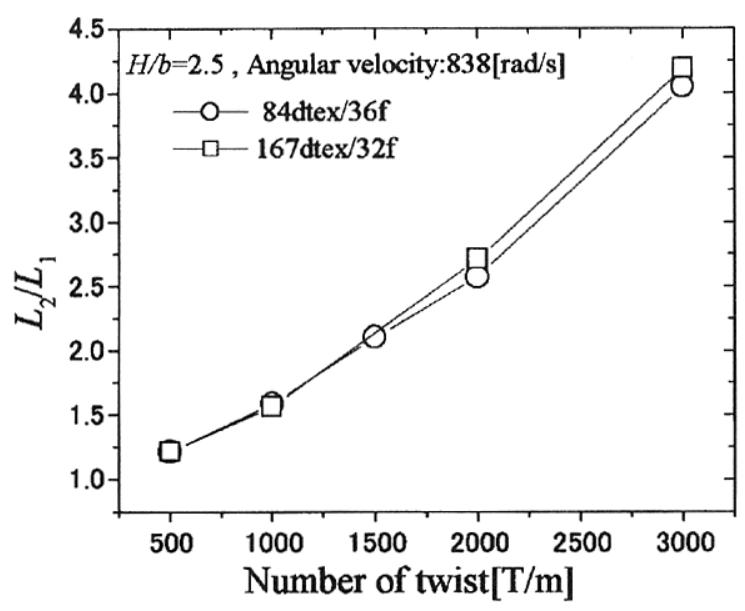

Fig. $7 L_{2} / L_{1}$ and number of twist

螺旋状に巻付くことが原因である. 一方，カバリング系の巻 付け張力の解析より，スピンドル角速度が同じならば, 撚数 が異なってもカバリング系の巻付け張力は同じとなり, 巻付 け張力によるカバリング糸の単位長さ当たりの伸びも同じ である. しかし，芯系の単位長さに対するカバリング系の長 さは撚数が多いほど長くなるので, スピンドル角速度の増加 に対する $L_{2} / L_{I}$ の堿少率は撚数が多いほど大きくなると考え られる.これにより，然数が同じであっても，スピンドル角 速度が異なるとカバリング系の巻付け張力が変わり, それに ともなって $L_{2} / L_{1}$ も変化することにより, カバード系の形状 も異なることがわかる。

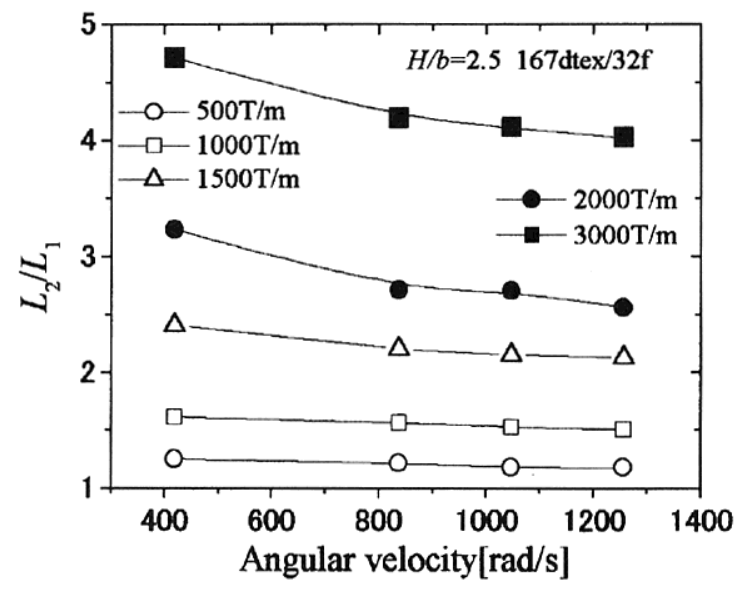

Fig.8 $L_{2} / L_{1}$ and angular velocity of spindle

図 9 に然数が同じであってもカバリング糸の巻付け張力 (スピンドル角速度）が異なることにより，カバリング糸が 芯系に螺旋状に巻付く状態が異なっている系の外観を示す. 図 9 の（a）と（b）を比較するとスピンドル角速度が速く カバリング系の巻付け張力が大きい（a ）ではカバリング系 のフィラメントが収束して巻付いているが, スピンドル角速 度が遅くカバリング糸の巻付け張力が小さい（b ）ではフィ ラメントは収束せずにバルキー性を保持しており, カバード

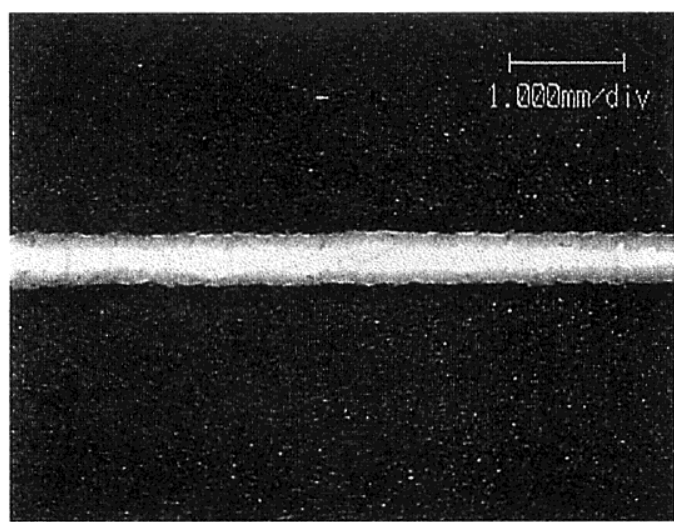

(a) $1257 \mathrm{rad} / \mathrm{s}$

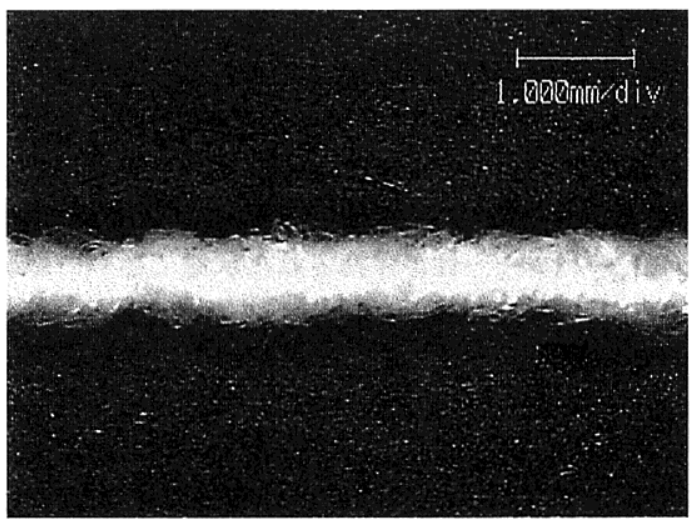

(b) $419 \mathrm{rad} / \mathrm{s}$

Fig.9 Appearance of covered yarn

(Covering yarn:184dtex/48f, $H / b: 2.5,3000 \mathrm{~T} / \mathrm{m}$ ).

系の外観も太くなっている.このことから，カバリング系の 巻付け張力が変化するとカバード系の構成比も異なり, カバ ード糸の形状が変化することがわかる.

図 10 は, 系種の違いによるスピンドルの角速度とカバー ド系の構成比との関係を示す. 系種が異なっても図 8 と同様 にスピンドル角速度の増加にともなって $L_{2} / L_{1}$ は堿少してい る. スピンドル角速度が $419 \mathrm{rad} / \mathrm{s}$ において 3 種類のカバリン グ系の $L_{2} / L_{1}$ を比較するとその差はかなり大きいが， スピン

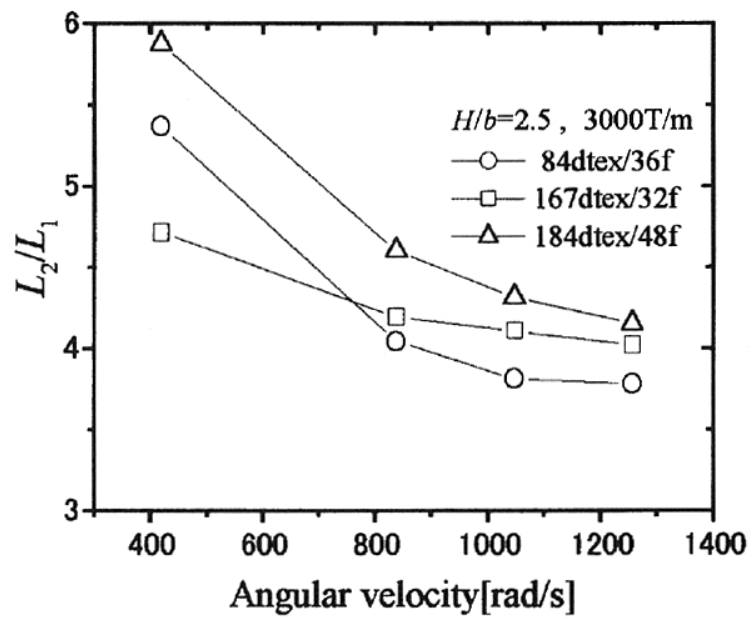

Fig. $10 L_{2} / L_{1}$ and angular velocity of spindle 


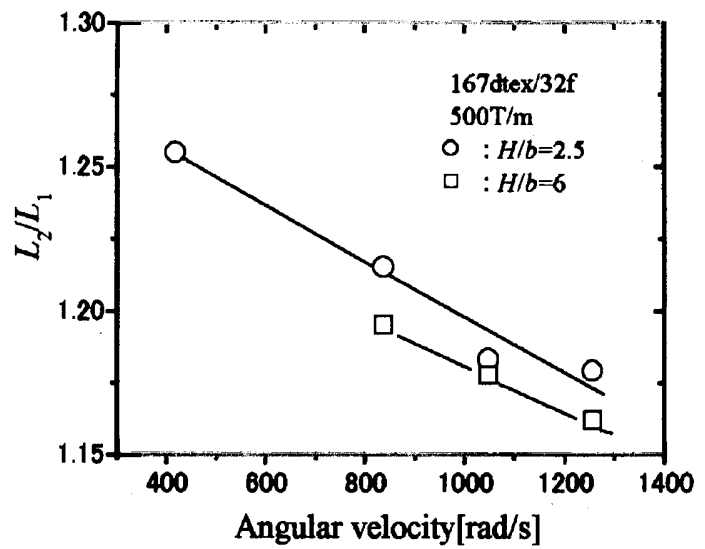

Fig. $11 L_{2} / L_{1}$ and angular velocity of spindle

ドル角速度が 838rad/s 以上では，その巠は小さくなってい る.これはスピンドル角速度が $419 \mathrm{rad} / \mathrm{s}$ における 3 種類の力 バリング系の巻付け張力は, 他のスピンドル角速度の場合と 比較すると最小となり，図 9 （b）より仮然系である 184dtex/48f のバルキー性が保持された状態で芯系に螺旋状 に巻付くので，他の 2 種類の糸と比較すると $L_{2} / L_{1}$ が最も大 きくなったと考えられる．また，仮然加工がされていない 167dtex/32f と 84dtex/36f 比較すると, スピンドル角速度が 419rad/s では 84dtex/36f の $L_{2} / L_{1}$ が大きくなっている.これは, 167dtex/32f より 84dtex/36f の巻付け張力が小さいので, 84dtex/36f は 167dtex/32f と比較して芯糸に対して柔らかく巻 付くので, 84dtex/36f の $L_{2} / L_{1}$ は 184dtex/48f より小さいが, 167dtex/32f より大きくなったと考えられる. スピンドル角速 库が $838 \mathrm{rad} / \mathrm{s}$ 以上では, 3 種類のカバリング禾は全て $419 \mathrm{rad} / \mathrm{s}$ の場合と比較して大きい張力で引っ張られフィラメントが 収束して芯系に螺旋状に巻付くので，カバリング系の直径が 大きいほど $L_{2} / L_{1}$ は大きくなったと考えられる.

図 11 は, 系層半径を一定とし, バルーン高さを変化させ て $H / b$ を変えた場合のスピンドル角速度とカバード系の構成 比の関保を示す. $H / b=6$ の場合におけるカバード系の粠成比 は, $H / b=2.5$ の值と比較して小さくなっている.これは，カ バリング系の巻付け張力の解析結果（図 5(b)) と一致し ており, 系層半径が一定の場合, 系層半径とバルーン高さの 比 $H / b$ が大きくなるとカバリング禾の巻付け張力も大きくな り，力バード禾の構成比が小さくなることがわかる. カバリ ング糸の巻付け張力制御の有無による $L_{2} / L_{I}$ の違いを図 12 に示す．スピンドル角速度とバルーン高さが一定の場合，系 層半径の減少にともない， $L_{2} / L_{1}$ が增加している.これは, 式 （4）とカバリング糸の巻付け張力の解析結果より, バルー ン高さが一定の場合, 乎層半径 $b$ の减少にともなう $\ell / b$ の増 加の影稫より, $b$ の減少の效果が大きいため, カバリング系 の巻付け張力が堿少することが原因である，また，（a）,

（b）を比較すると全体的にバルーン高さが高い（b）の方 がカバード系の構成比が小さくなっていることがわかる.こ れは, 図 11 の結果と同様に系層半径が同じ場合, $H / b$ が大 きいとカバリング糸の巻付け張力も大きくなることが原因

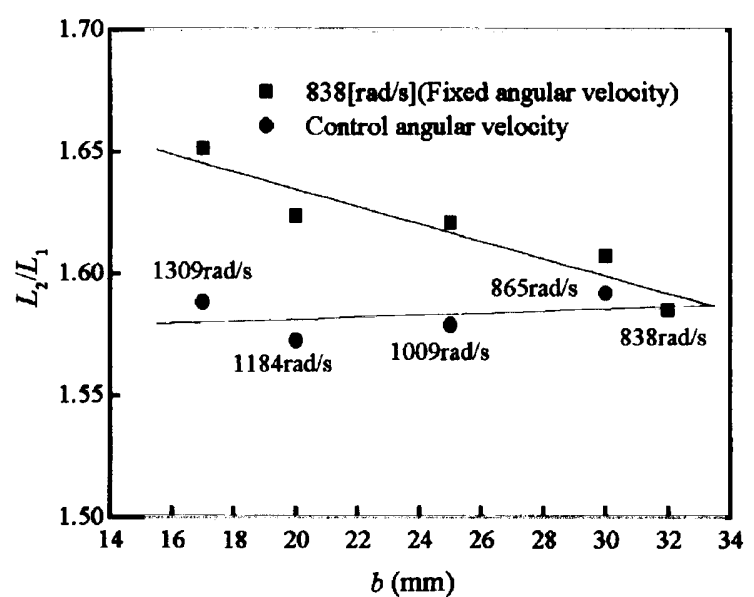

(a) $H=65 \mathrm{~mm}$

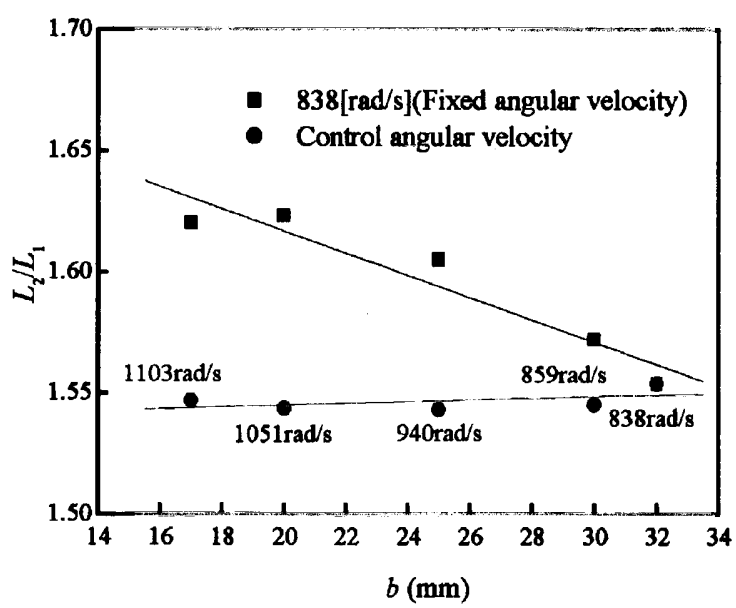

(b) $H=100 \mathrm{~mm}$

Fig.12 Effect of control of spindle angular velocity for $L_{2} / L_{1}$

と考えられる. 一方, スピンドル角速度を変えてカバリング 系の巻付け張力を一定とする手法を用いた場合は, $L_{2} / L_{1}$ が禾 層半径の変化の影警をあまり受けていないことがわかる.こ の結果から，カバリング系の巻付け張力の解析より系層半径 の変化に忍じてスピンドル角速度を変えてカバリングする 手法は, 系層半径の减少により， $L_{2} / L_{1}$ が小さくなることを防 ぐ効果があることがわかる。

\section{5. 結 論}

カバリングエ程におけるカバリング糸の巻付け張力とカ バード系の構成比の関係を調べた結果，以下の結論を得た.

（1）然数が同じであっても，スピンドル角速度の増加にと もない, カバリング糸の巻付け張力は増加するため力 バード系の棈成比は诚少する.

（2）系層半径が一定の場合, 系層半径とバルーン高さの比 $H / b$ が大きくなると, カバリング系の巻付け張力が大 きくなるため, カバード禾の構成比は堿少する.

（3）バルーン高さが一定の場合, 系層半径とバルーン高さ の比 $H / b$ が大きくなるとカバリング系の巻付け張力は 
小さくなるため, カバード系の構成比は増加する.こ れを防ぐため, カバリング系の巻付忛張力が一定とな るようカバリング系の巻付け張力の解析より釆層半 径の変化に忘じてスピンドル角速度を変えてカバリ ングする手法は, カバード禾の構成比を安定させるの に有効である.

\section{莭 辞}

本研究を行うにあたり，適切なアドバイスを頂いた石川県 工業試䀦場の新谷隆二氏と中島明哉氏，また，実畭にご協力
いただいた金沢大学の大霞友雄氏, 安藤陽星氏, 今井裕也氏 に感謝の意を表します。

\section{References}

[1] Shintaku, S. Yoshimura, G. Iwaki, N.; Seni-Gakkaishi, 34, T316(1979)

[2] Shintaku, S. Yoshimura, G.; Seni-Gakkaishi, 36, T75(1980)

[3] C. Mack, E. L. Smart; J, Text. Inst., 47, T394(1956)

[4] Yamamoto, T. Shintaku, S.; Seni-Gakkaishi, 44, T40(1988) 